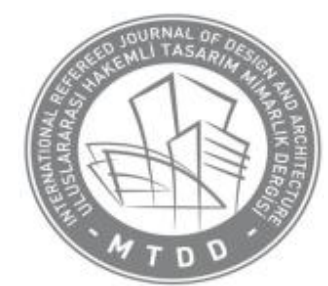

ULUSLARARASI HAKEMLI TASARIM VE MIMARLIK DERGISI

INTERNATIONAL REFEREED JOURNAL OF DESIGN AND ARCHITECTURE

Ocak / Şubat / Mart / Nisan 2014 Sayı: 01 Cilt: 01 Ilkbahar Dönemi

January / February/March / April 2014 Issue: 01 Volume: 01 Spring Semester

ID:22 K:21

www.mtddergisi.com

\title{
AN ENVIRONMENTALLY FRIENDLY TYPE OF BUILDING: GREEN BUILDINGS
}

\author{
A.Esra CENGIZZ ${ }^{1}$, Aybike Ayfer KARADA $\breve{G}^{2}$, Cemal Onur ALPAY \\ ${ }^{1}$ ÇOMÜ Mimarlık ve Tasarım Fakültesi Peyzaj Mimarlı̆̆ı Bölümü \\ ${ }^{2}$ Düzce Üniversitesi Orman Fakültesi Peyzaj Mimarlığı Bölümü \\ ${ }^{3}$ Odak Peyzaj Tasarım/İmir
}

\begin{abstract}
Today the rapidly degrading natural environment is continually leading the human being to new and different searches. Especially the green areas which have decreased with an increase in building and the resulting degradation in the ecosystem cycle are among the most fundamental reasons for these searches. Although pains are being taken today to increase the green areas around buildings along with buildings, there is now a need for more systematic formations which protect and develop the natural environment. Appearing under many names such as sustainable, ecological, green, and environmentally friendly, green buildings correspond to a crucial shortcoming at this point. In this context, green buildings standing out as the productive buildings which are in harmony with the environment and part of the ecological balance should be in the position of a productive system which contributes to the sustainable urban life besides protecting and developing the natural habitat in the environment. First of all, the definition of a green building, its features and green building assessment systems will be addressed in this study. Later on, the examples of green buildings both in our country and worldwide will be investigated and how important green building systems are to a sustainable environment will be dwelled on. Finally, in the light of these data, the current point reached in the studies on green buildings in our country and evaluations on this result will be included.
\end{abstract}

Key Words: Ecology, Ecosystem, Green Building, Green Tuilding Assessment System, Sustainability

\section{ÇEVRE DOSTU BİNALAR: YEŞİL BİNALAR}

Özet: Günümüzde hızla bozulan doğal çevre, insanoğlunu devamlı olarak yeni ve farklı arayışlara götürmektedir. Özellikle yapılaşmanın artmasıyla azalan yeşil alanlar ve bunun sonucunda ortaya çıkan ekosistem döngüsündeki bozulmalar, bu arayışın en temel nedenlerindendir. Günümüzde her ne kadar yapılarla birlikte çevresindeki yeşil alanların arttırılmasına özen gösterilse de, artık doğal çevreyi koruyan ve geliştiren daha sistemli 


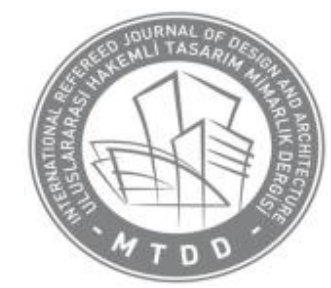

\author{
ULUSLARARASI HAKEMLI TASARIM VE MIMARLIK DERGISI \\ INTERNATIONAL REFEREED JOURNAL OF DESIGN AND ARCHITECTURE \\ Ocak / Şubat / Mart / Nisan 2014 Sayı: 01 Cilt: 01 İlkbahar Dönemi \\ January / February/March / April 2014 Issue: 01 Volume: 01 Spring Semester \\ ID:22 K:21 \\ $\underline{w w w . m t d d e r g i s i . c o m}$
}

oluşumlara ihtiyaç bulunmaktadır. Sürdürülebilir, ekolojik, yeşil, çevre dostu vb. pek çok isim altında karşımıza çıkan yeşil binalar ise işte bu noktada çok önemli bir eksiğe karşılık gelmektedir. Bu bağlamda, çevre ile uyumlu ve ekolojik dengenin bir parçası olan üretici yapılar olarak ön plana çıkan yeşil binalar; çevredeki doğal yaşam alanını koruma ve geliştirmenin yanı sıra sürdürülebilir kent yaşamına katkıda bulunan üretici bir sistem durumunda olmalıdır. Bu çalışmada; öncelikle yeşil binanın tanımı, özellikleri ve yeşil bina değerlendirme sistemlerine değinilecektir. Daha sonra ülkemizde ve dünyada yer alan yeşil bina örnekleri incelenerek yeşil bina sistemlerinin sürdürülebilir bir çevre için ne derece önemli olduğu üzerinde durulacaktır. Son olarak, bu veriler ışığında ülkemizdeki yeşil binalar ile ilgili yapılan çalışmalarda hangi noktaya gelindiği ve bu sonuç ile ilgili değerlendirmelere yer verilecektir.

Anahtar Kelimeler: Ekoloji, Ekosistem, Yeşil Bina, Yeşil Bina Değerlendirme Sistemi, Sürdürülebilirlik

\section{INTRODUCTION}

Sustainability is a positive concept which has stood out with such words as "green, ecological, climate and environmentally friendly, and zero energy" in the recent years and actually aims to reach a better human life and ecosystem cycle (Vural et al., 2013). One of the greatest obstacles to the sustainable balance in the ecosystem is the phenomenon of urbanization, which has developed depending on the population increase. Unfortunately, a building sector considerably far from the understanding of sustainable architecture is developing in the process of urbanization. However, not consumption- but production-oriented building logic must be developed for the formation and continuation of a sustainable environment today. As Erten (2011) also states, the construction sector has now been ahead of the other sectors regarding the increase in carbon footprints. Using one-third of the natural resources, this sector uses $12 \%$ of fresh water, while it is responsible for $40 \%$ of the total solid wastes too.

As seen, it is not very wrong to indicate the unconsciously developing building sector as the chief architect of the gradually increasing environmental pollution and degrading ecosystem cycle today. In this context, although it is not a very realizable action to somehow prevent the housing sector, which is developing at a great pace depending on the increasing population, an environmentally friendly building understanding must be encouraged in the sector. Standing out at this point and being one of the concepts which have come to mind first in the recent years when the environmentally friendly building design is considered, "green building" seems to be one of the best solutions that might prevent the destruction urbanization has caused in 


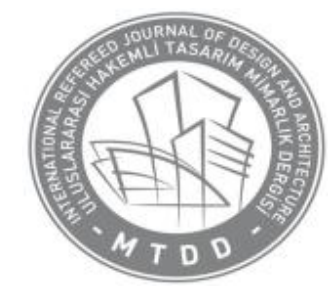

\author{
ULUSLARARASI HAKEMLI TASARIM VE MIMARLIK DERGISİ \\ INTERNATIONAL REFEREED JOURNAL OF DESIGN AND ARCHITECTURE \\ Ocak / Şubat / Mart / Nisan 2014 Sayı: 01 Cilt: 01 İlkbahar Dönemi \\ January / February / March / April 2014 Issue: 01 Volume: 01 Spring Semester \\ ID:22 K:21 \\ $\underline{w w w . m t d d e r g i s i . c o m}$
}

the natural environment. Green buildings offer innumerable concrete benefits.

"Green" or "sustainable" buildings use energy, water and materials most efficiently in the buildings to be constructed for more natural light, better air quality, human health, and comfort (Kats, 2003).

In the study, information on the concept of green building, the differences which distinguish green buildings from other buildings, the main factors which must be examined in green buildings, green building assessment systems, foreign and domestic examples of green buildings, and the possibilities of applying green buildings in our country will be provided and recommendations will be made on the matter.

\section{THE CONCEPT OF GREEN BUILDING}

To reveal the need for green buildings and to carry out successful green building designs and productions, first of all, the definition of a green building must be understood, as also emphasized by Erten (2011).
There are many definitions of green buildings (Kats, 2003; Kalataş, 2008; Erlalelitepe et al., 2011; Erten, 2011; Terekli et al., 2013).

In order for buildings to be identified as green, they must, first of all, meet specific standards in fields such as sustainable land planning, water and waste management, water saving, provision of natural daylight, recycling and waste reduction, the use of ecological materials, interior air quality, a healthy indoor space, user health and comfort, transportation and energy control, renewable energy, acoustics and pollution, hygiene, and environmental quality (Figure 2.1). Besides, in order for green buildings to be of a high level of environmental quality, the level of general satisfaction with the standards in question must be at the highest level. An ideal "green building" should be a producer that is able to generate resources, energy, and water instead of being a consumer besides conserving and renewing the living space around it. In other words, green buildings should contribute to the prolongation of the ecosystem cycle through durable, flexible, and adaptable design (Abbaszadeh et al., 2006; Erten, 2011; Terekli et al., 2013; Anonymous, 2014a; Anonymous, 2014b). 


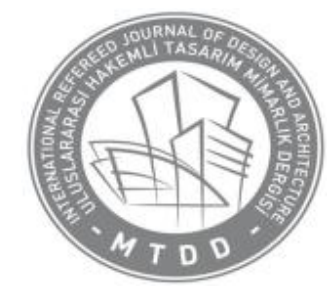

ULUSLARARASI HAKEMLI TASARIM VE MIMARLIK DERGISII

INTERNATIONAL REFEREED JOURNAL OF DESIGN AND ARCHITECTURE

Ocak / Şubat / Mart / Nisan 2014 Sayl: 01 Cilt: 01 İlkbahar Dönemi

January / February/March / April 2014 Issue: 01 Volume: 01 Spring Semester

ID:22 K:21

www.mtddergisi.com

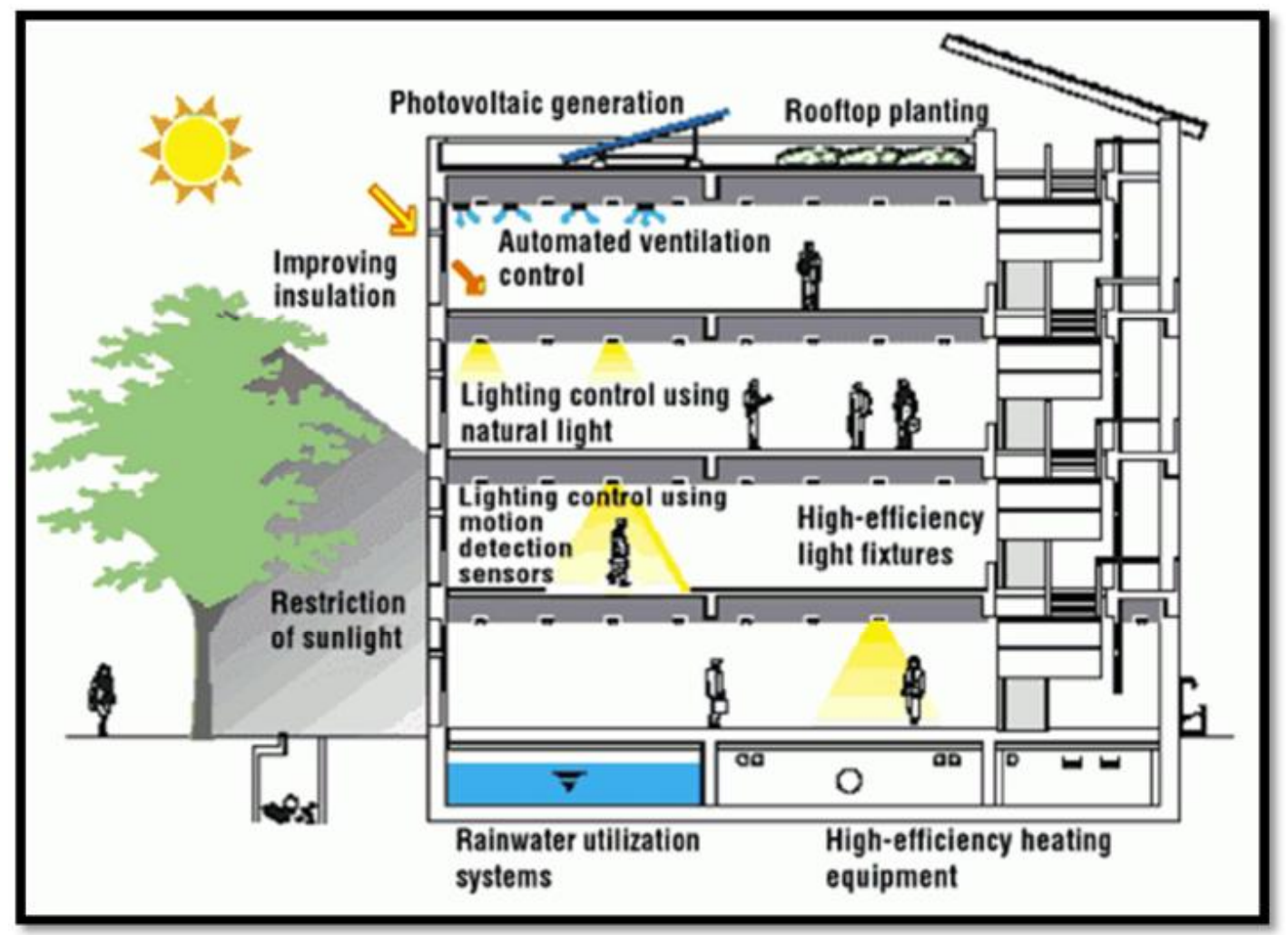

Figure 2.1. Conceptual Drawing Of Green Buildings (Zafar, 2013)

In a definition, Terekli et al. (2013) mentioned that a green building was better designed in terms of its impact on the environment than an average building, while, in another definition, they stressed that green buildings were defined as buildings which created tangible development and renewal in their environment. In their simplest and most general definition, Kincay (2008a) defined green buildings as the buildings which were designed, constructed, renewed, and operated in such a way that they could use natural resources efficiently.

\section{CHARACTERISTICS OF GREEN BUILDINGS}

Green buildings are constructed to enable people to integrate with nature most efficiently; to protect the health of their inhabitants; to enhance the efficiency of employees; to use water, energy, and other resources more efficiently; and to minimize the possible negative environmental impacts (Kincay, 2008a). In this context, green buildings have both advantages and disadvantages. Especially the cost of application and structural harmony of green buildings are their 


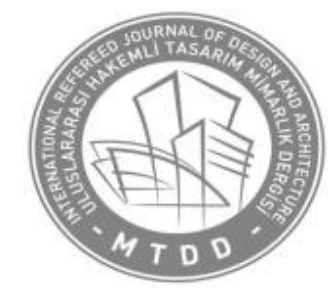

\author{
ULUSLARARASI HAKEMLI TASARIM VE MIMARLIK DERGISI \\ INTERNATIONAL REFEREED JOURNAL OF DESIGN AND ARCHITECTURE \\ Ocak / Şubat / Mart / Nisan 2014 Sayı: 01 Cilt: 01 İlkbahar Dönemi \\ January / February/March / April 2014 Issue: 01 Volume: 01 Spring Semester \\ ID:22 K:21 \\ $\underline{w w w . m t d d e r g i s i . c o m}$
}

disadvantageous features. The advantages of green buildings are collected under a total of six main headings, namely efficient technologies, easy maintenance, developed interior air quality, return of the investment, energy efficiency, and tax incentives (Anonymous, 2014c). Ries et al. (2006) stated that the advantages of green buildings were the efficiency of employees in particular as well as the reduction of health and security costs and saving and gains in energy, maintenance, and transportation costs. Participation of all stakeholders, purification of grey water and recovery of rainwater, efficient use of energy and the use of alternative energy, the use of materials which do not damage the environmental quality, application activities sensitive to the environment, and maintenance of the buildings after application should be ensured in the process of designing and applying green buildings. In addition, those areas which particularly support rainwater control and biodiversity and prevent the heat island and light pollution (Anonymous, 2014d) should be preferred when selecting the location of buildings.

In summary, a green building is a way of enhancing the environment. It benefits humans, the community, the environment, and a builder's bottom line. It is about tailoring a building and its site to the local climate, site conditions, culture and community in order to reduce resource consumption while enhancing the quality of life. There is no singular "look" for a green building. While natural and resource efficient features can be highlighted in a building, they can also be invisible within any architectural design (Karolides, 2002).

\section{GREEN BUILDING ASSESSMENT SYSTEMS}

The National Green Building Councils around the world set forth that one of the most effective ways of making green buildings widespread was to grant a "green tag" to these buildings. An "ecolabel" is available for the food we eat or the products we purchase. Just the same may be applied to buildings, which is a positive step to encourage these buildings and make them widespread. Thanks to these labels, the greenness of a building is registered within the framework of some standards (Anonymous, 2014e). Additionally, inhabitants of buildings should have an opportunity of accessing any technical information from the quality of air they breathe in the building to the amount of carbon released as a result of the energy used. Therefore, the certificate system in green buildings is a quite important issue (Anonymous, 2014e; Kıncay, 2008a).

The system to be selected might create some problems in terms of application, design, and cost. A correct certificate system enables application and design to be of good quality and ensures the creation of appropriate and healthy interior quality for users (Erlalelitepe et al., 2011). Since the sustainability of a building can only be assessed according to the local environment where the building is located, every country develops its local green 


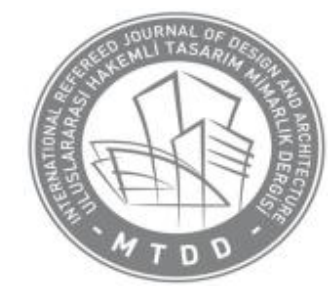

\author{
ULUSLARARASI HAKEMLI TASARIM VE MIMARLIK DERGISI \\ INTERNATIONAL REFEREED JOURNAL OF DESIGN AND ARCHITECTURE \\ Ocak / Şubat / Mart / Nisan 2014 Sayl: 01 Cilt: 01 Ilkbahar Dönemi \\ January / February / March / April 2014 Issue: 01 Volume: 01 Spring Semester \\ ID:22 K:21 \\ $\underline{w w w . m t d d e r g i s i . c o m}$
}

building assessment system on the basis of its own legal documents, market condition, and needs. Today there are more than thirty local assessment systems which are being used by different countries (Erten, 2011; Zafar, 2013). Many green building standards and certificates are available worldwide. The most used ones among them are as follows (Kincay, 2008a):

LEED (Leadership in Energy and Environmental Design); BREEAM (Building Research Establishment Environmental Assessment Method); GREEN STAR (It was drawn up by the Green Building Council of Australia by examining the criteria of LEED and BREEAM); DGNB (The newly formed green building certificate of the German Green Building Council); BEES (Building for Environmental and Economic Sustainability); SBtool (Sustainable Building Tool-Canada); ECO-QUANTUM (a simulation-based model); ECOPROFILE (for existing office buildings); LCAid (based on the life cycle analysis); and CASBEE (The certificate of the Japanese which was formed with state support).
Those regarded as the most developed ones among these assessment systems are the BREEAM certificate system of English origin, which has been used since 1990, and the LEED certificate system of US origin, which began to be used in 1998 (Erten, 2011; Zafar, 2013).

\section{EXAMPLES OF GREEN BUILDINGS}

The studies on green buildings are also rapidly increasing in our country. Environmentally friendly green buildings have more than one area of use (new constructions, comprehensive renewal activities, rough constructions, school buildings, detached houses, urban transformation, and interior design projects); furthermore, a new one is added to them every day (Katz, 2012).

In the USA, the 7 World Trade Center in New York received the first "Golden" certificate and became the first green building in the USA within the framework of the LEED program of the USGBC (US Green Building Council) (Figure 5.1) (Kincay, 2008b). 


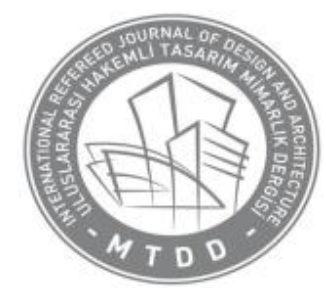

ULUSLARARASI HAKEMLI TASARIM VE MIMARLIK DERGISII

INTERNATIONAL REFEREED JOURNAL OF DESIGN AND ARCHITECTURE

Ocak / Şubat / Mart / Nisan 2014 Sayl: 01 Cilt: 01 İlkbahar Dönemi

January / February/March / April 2014 Issue: 01 Volume: 01 Spring Semester

ID:22 K:21

$\underline{w w w . m t d d e r g i s i . c o m}$

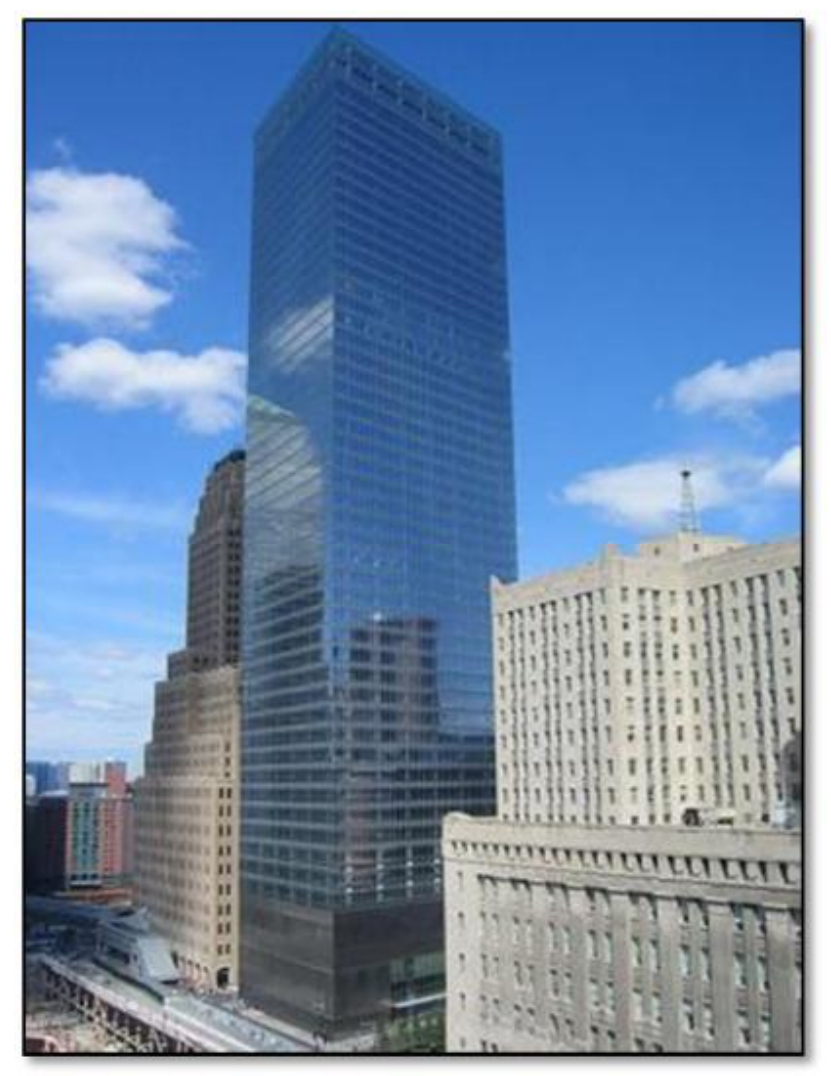

Figure 5.1. The 7 World Trade Center (Anonymous, 2014f)

In Turkey, the RMI Turkish Research and Training Center received the reward of the first and only environmentally friendly building granted a "green building" status in 2006 by the European Joint Research and Training Center (Figure 5.2) (Kıncay, 2008c; Esin and Yüksek, 2009).

The following are some of the important examples of green buildings both in the country and abroad (Figures 5.3 and 5.4). 
ULUSLARARASI HAKEMLI TASARIM VE MIMARLIK DERGISI INTERNATIONAL REFEREED JOURNAL OF DESIGN AND ARCHITECTURE

Ocak / Şubat /Mart / Nisan 2014 Sayı: 01 Cilt: 01 Ilkbahar Dönemi January / February / March / April 2014 Issue: 01 Volume: 01 Spring Semester

ID:22 K:21

www.mtddergisi.com

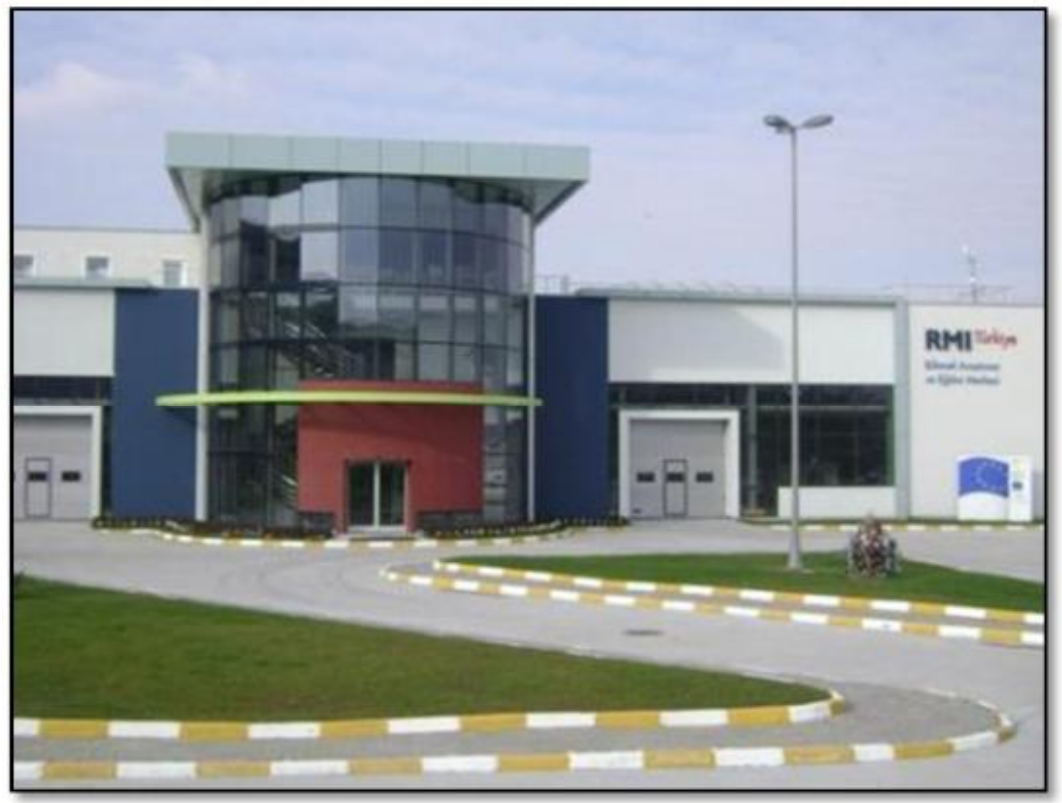

Figure 5.2. The RMI Turkish Research and Training Center (Anonymous, 2014g)
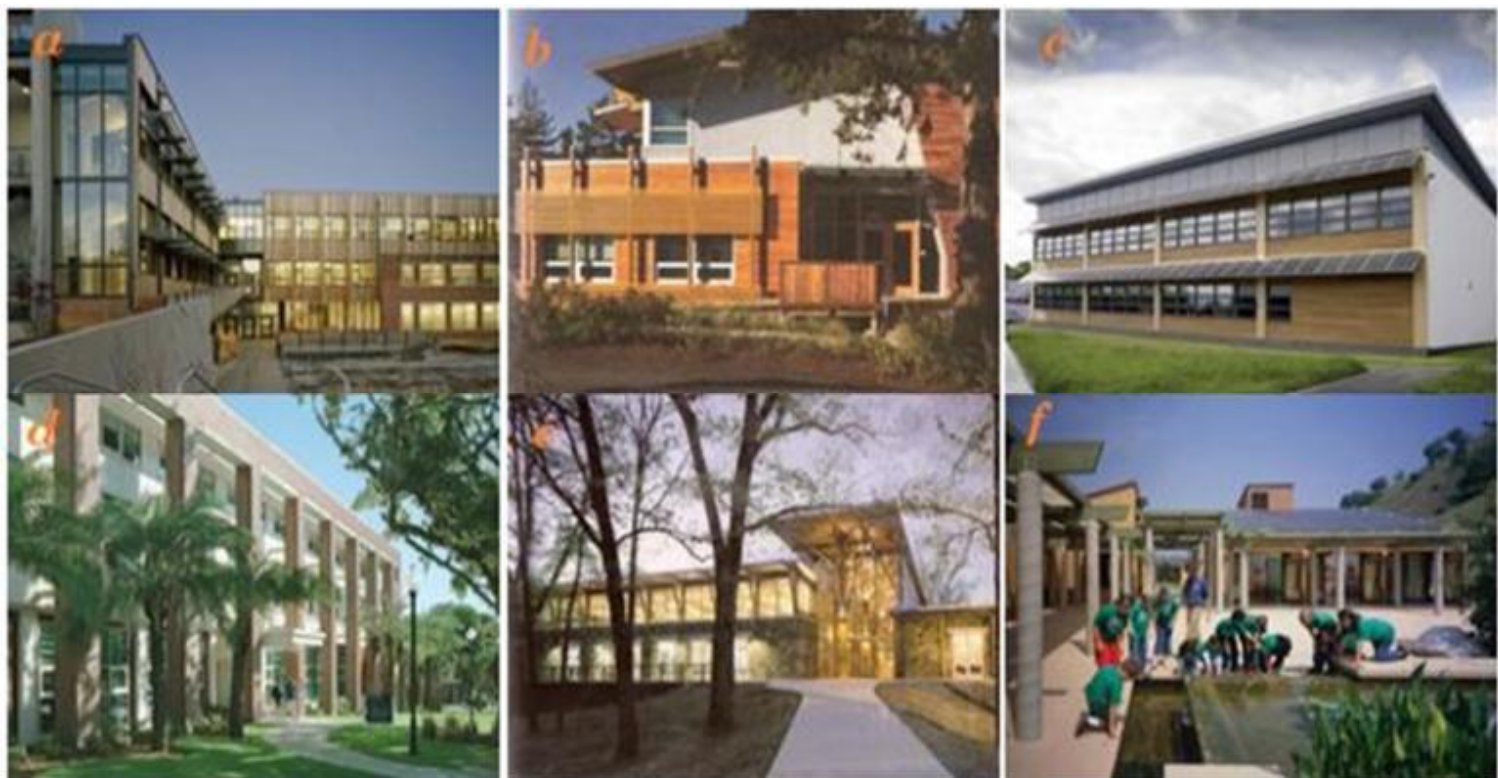

Figure 5.3. Examples of Green Buildings from the World (a. Sidwell School, b. Gulf Islands Operations Centre, c. The Office of Defra, d. Camp Aldersgate Commons, e. Rinker Hall, and f. Audubon Center) (Anonymous, 2014e) 


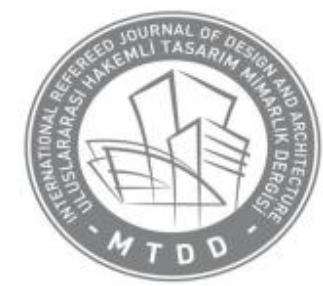

ULUSLARARASI HAKEMLI TASARIM VE MIMARLIK DERGISI

INTERNATIONAL REFEREED JOURNAL OF DESIGN AND ARCHITECTURE

Ocak / Şubat / Mart / Nisan 2014 Sayl: 01 Cilt: 01 İlkbahar Dönemi

January / February/March / April 2014 Issue: 01 Volume: 01 Spring Semester

ID:22 K:21

www.mtddergisi.com

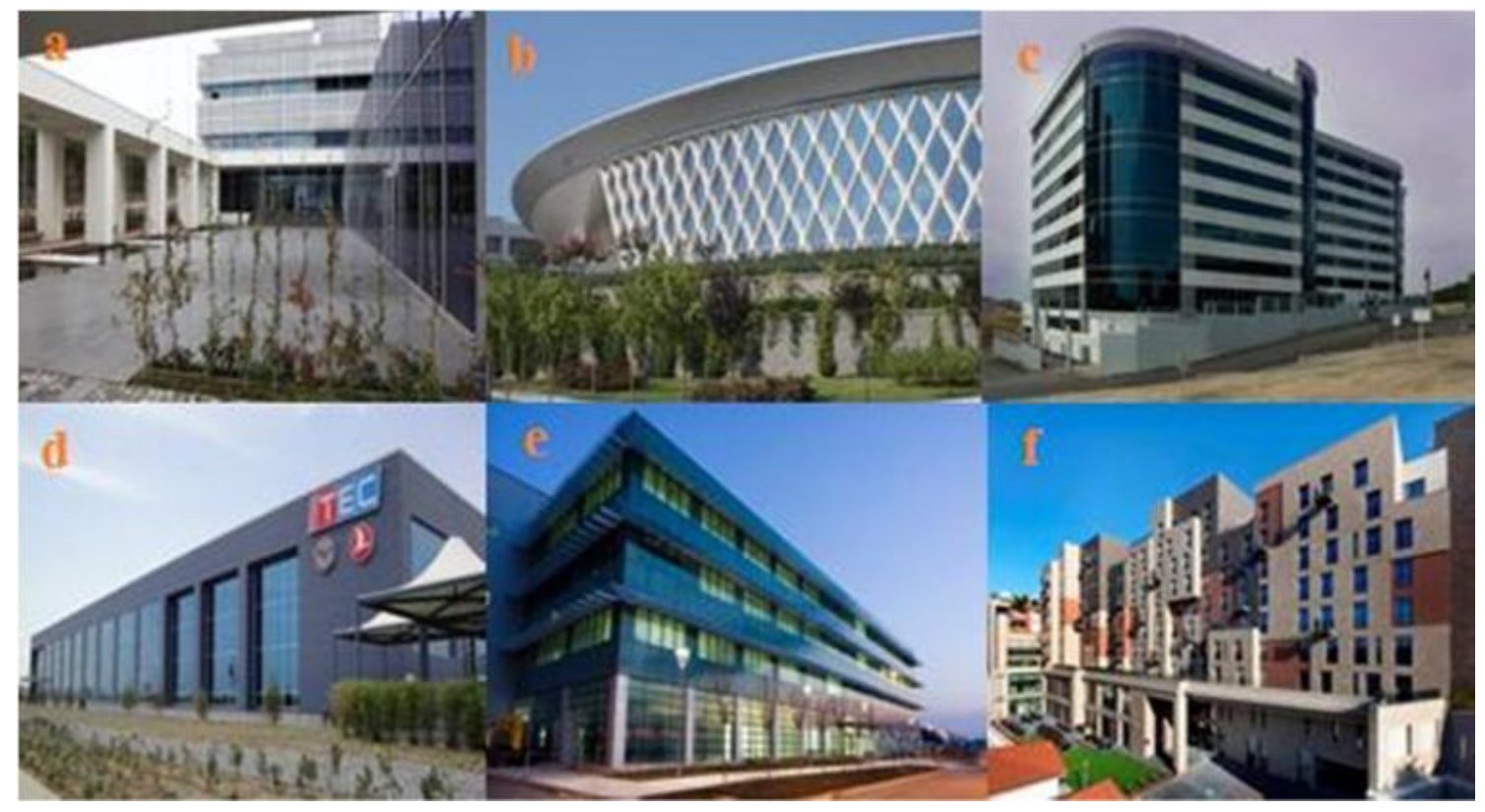

Figure 5.4. Examples of Green Buildings from Turkey (a. Çekmeköy Campus of Özyeğin University, b. Sabancı University Nanotechnology Center, c. Ümraniye Office of Unilever, d. Pratt \& Whitney Turkish Technic Aircraft Engine Maintenance Center, e. GOSB Facility of Siemens, and f. Hotel Hilton Garden Inn İstanbul Golden Horn)

(Kincay, 2008c; Anonymous, 2014d)

\section{THE SITUATION OF GREEN BUILDING PRACTICES IN OUR COUNTRY}

In Turkey, the ÇEDBİK (The Association of Environmentally Friendly Green Buildings) is a nongovernmental organization which was founded in 2007 under the World Green Building Council (WGBC). Moreover, it is the sole institution which represents Turkey under the roof of the WGBC. The councils pass through the WGBC membership with a total of four stages in the process of becoming an established council, namely the stages of "associated", "prospective", "emerging", and "established" statuses. The ÇEDBIKK acquired the "emerging" status, the third of these stages, in September 2009 (Erten, 2011). The Association of Environmentally Friendly Green Buildings was granted "the Established Council Status" in June 2012 by "the World Green Building Council (WGBC)", and it is carrying on the studies of building the infrastructure of the green building movement with gradually increasing participation. Following national and international developments in this field, the Building Code and Certification Committee of the Association of Environmentally Friendly Green 


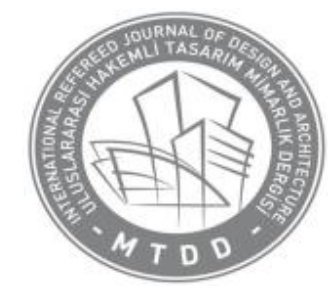

\author{
ULUSLARARASI HAKEMLI TASARIM VE MIMARLIK DERGISI \\ INTERNATIONAL REFEREED JOURNAL OF DESIGN AND ARCHITECTURE \\ Ocak / Şubat / Mart / Nisan 2014 Sayl: 01 Cilt: 01 Ilkbahar Dönemi \\ January / February / March / April 2014 Issue: 01 Volume: 01 Spring Semester \\ ID:22 K:21 \\ $\underline{w w w . m t d d e r g i s i . c o m}$
}

Buildings began its studies in order to create an assessment system convenient for national conditions with the participation of names specialized in their own field so as to fill an important gap in our country (Anonymous, 2014e).

The mission of the ÇEDBİK is to pioneer the development of the construction sector in Turkey in the light of sustainable principles. The ÇEDBIK, which has close relationships with both public and private institutions in this respect, holds training and conferences and develops pilot projects in order for green buildings to become widespread in Turkey. The purpose of foundation of the ÇEDBİK is to spread the concept of green building at the grass-roots level as much as possible and increase the number of green buildings constructed as a result of integrated design. Since such certificates are prepared according to the conditions of the country where they are drawn up, their application in Turkey brings about many challenges. Implementation of different standards in Turkey, selection of materials and technology and qualified employees are some of these challenges. This directs those who intend to construct a green building to abroad. It signed goodwill agreements with the international institutions responsible for the LEED, BREEAM, and DGNB certificates. To overcome these challenges and accelerate the process of making green buildings widespread, the ÇEDBİK signed a goodwill agreement with BRE-Global and initiated studies on the adaptation of
BREEAM to Turkey. Furthermore, the association also signed goodwill agreements with the international institutions responsible for the LEED and DGNB certificates (Erten, 2011).

\section{RESULTS AND DISCUSSION}

The global climate changes, the most serious problem of the Earth we are living on today, manifest themselves as the final consequence of the gradually increasing environmental problems. As Erten (2011) also stated, environmental problems such as the decrease in agricultural land and forestland, contamination of waters, the commencement of water shortage, the thinning of the ozone layer depending on the increasing greenhouse gases, the danger of drought, the fact that wetlands are endangered, air pollution, and the gradual degradation of the ecosystem balance have begun to be pronounced more frequently in the recent years. Even though environmental problems have various causes, the phenomenon of increasing urbanization and the sectors developing accordingly are standing out as the most important causes today.

The fact that urbanization and the housing sector that developed accordingly had such a role in the environmental problems forced people and institutions to new searches so as to prevent this. Green buildings, which occur at this point and are one of the concepts that have come to mind first in the recent years when the ecological structure is considered, are regarded as a 


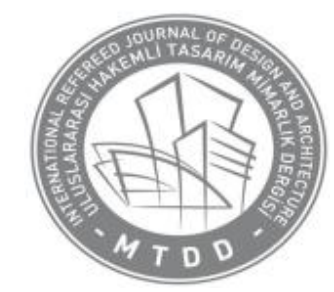

\author{
ULUSLARARASI HAKEMLI TASARIM VE MIMARLIK DERGISI \\ INTERNATIONAL REFEREED JOURNAL OF DESIGN AND ARCHITECTURE \\ Ocak / Şubat / Mart / Nisan 2014 Sayı: 01 Cilt: 01 İlkbahar Dönemi \\ January / February/March / April 2014 Issue: 01 Volume: 01 Spring Semester \\ ID:22 K:21 \\ $\underline{w w w . m t d d e r g i s i . c o m}$
}

solution that might change the direction of this bad course.

The construction and multiplication of green buildings should be one of the environmental strategies that must be brought to the forefront under the present conditions under which the ecosystem balance is being completely upset. Kincay (2008c) stated that the harmony of a building with its environment, energy yield, the yield of the materials used in the construction of the building, water yield, user health and security and the criteria for purchasability must be taken as the basis for the construction of a green building. Depending on this reality and as Kats (2003) also stated, it must be stressed that the construction of green buildings is definitely much costlier than that of standard buildings. However, the production of environmentally friendly materials is particularly more limited in Turkey than that abroad, and such materials are primarily required in the construction of green buildings. Nevertheless, some increase in this matter is observed in parallel with the environmental consciousness that has increased in the recent years. Since the costs and taxes of green buildings are very high and the incentives of the state on this matter are also limited, the development of green buildings in our country is unfortunately more slowly than that abroad. To minimize the environmental problems and create a sustainable environment today, the construction of green buildings must be encouraged and institutional support must be at the highest level in the process of development of green buildings in our country. In this context, it is also of extreme importance to support the development of the production of ecological materials primarily used in green buildings in our country in order to cut down on the cost due to purchases from abroad.

Yazar Notu: Bu calısma ilgili yazarlar tarafindan 2014 yol Nisan ayında İmir'de yapulan GreInSus'2014 Konferansı'nda poster bildiri olarak sunulmuștur.

\section{REFERENCES}

ANONYMOUS, (2014a). "Green Buildings", Accessed at www.buildform.in/green-buildings.html, Date of Access: 18.01.2014

ANONYMOUS, (2014b). "Why Green Buildings?", Accessed at www.leedintl.net/why_green_buildi ngs, Date of Access: 19.01 .2014

ANONYMOUS, (2014c). "Green Building: Advantages \& Disadvantages", Accessed at www.laborlawcenter.com/tgreenbuilding.aspx, Date of Access: 18.01.2014

ANONYMOUS, (2014d). "Green Building Studies", Accessed at www.arkitera.com/haber/index/deta y/yesil-bina-etutleri/12984, Date of Access: 18.01.2014 


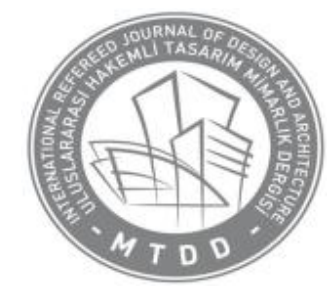

ULUSLARARASI HAKEMLI TASARIM VE MIMARLIK DERGISII

INTERNATIONAL REFEREED JOURNAL OF DESIGN AND ARCHITECTURE

Ocak / Şubat / Mart / Nisan 2014 Sayı: 01 Cilt: 01 İlkbahar Dönemi

January / February/March / April 2014 Issue: 01 Volume: 01 Spring Semester

ID:22 K:21

\section{www.mtddergisi.com}

ANONYMOUS, (2014e). "The Association of Environmentally Friendly Green Buildings", Accessed at www.cedbik.org/sayfalar.asp?KatI $\mathrm{D}=2 \& \mathrm{ID}=19$, Date of Access: 18.01.2014

ANONYMOUS, (2014f). "The 7 World Trade Center" Accessed at http://nyc-

architecture.com/NEW/AAGAAR0

7.htm, Date of Access: 18.01.2014

ANONYMOUS, (2014g). "Green Building Status the Given First Building from Turkey: RMI-Turkey", Accessed at www.mimarizm.com/kentintozu/M akale. $\operatorname{aspx} ? \mathrm{id}=474 \& \operatorname{sid}=461$, Date of Access: 18.01.2014

KATZ, A., (2012). "About LEED", Accessed at www.usgbc.org/articles/about-leed, Date of Access: 20.12.2013

KAROLIDES, A., (2002). "An Introduction to Green Building", Accessed at www.rmi.org, Date of Access: 19.02.2014

ERTEN, D., (2011). "Green Buildings, Sustainable Production and Consumption Publications-V (The Ministry of Environment and Urbanism)", ISBN: 978-975-618042-6. Ankara.

KATS, G., (2003). "Green Building Costs and Financial Benefits", Published in the USA for Massachusetts Technology Collaborative, USA. Accessed at http://www. bankerandtradesman.com/pub/4_91 /commercial/185123-1.html, Date of Access: 01.02.2014

KALATAŞ, H., (2009). "LEED ${ }^{\mathrm{TM}}$ Green Building Certification Program", The 9th National Congress on Sanitary Engineering, İzmir, May 2009, 1069-1078. Accessed at www.mmo.org.tr/resimler/dosya_e kler/d7c40dff67bbd25_ek.pdf, Date of Access: 01.02.2014

ERLALELITEPE, I., GÖKÇEN, G., KAZANASMAZ, T., (2011). "Importance of House Design in Green Building Certificate Systems", The 10th National Congress on Sanitary Engineering, Izmir, April 2011, 1625-1633. Accessed at www.mmo.org.tr/resimler/dosya_ek ler/f0413189c4ae885_ek.pdf, Date of Access: 08.02.2014

VURAL, N., ENGIN, N., VURAL, S., (2013). "Examples of Housing Estates in Turkey in the Context of Sustainability", The 11th National Congress on Sanitary Engineering, İzmir, April 2013, 997-1010. Accessed at https://docs.google.com/file/d/0B0CJ3XhQ0E6ZW10bEprSGRxLW M/edit?pli=1, Date of Access: 10.02.2014 


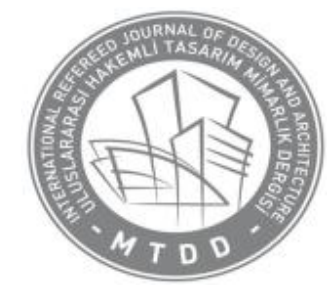

ULUSLARARASI HAKEMLI TASARIM VE MIMARLIK DERGISII

INTERNATIONAL REFEREED JOURNAL OF DESIGN AND ARCHITECTURE

Ocak / Şubat / Mart / Nisan 2014 Sayı: 01 Cilt: 01 İlkbahar Dönemi

January / February/March / April 2014 Issue: 01 Volume: 01 Spring Semester

ID:22 K:21

\section{$\underline{w w w . m t d d e r g i s i . c o m}$}

KINCAY, O (a)., (2008). "Sustainable Green Buildings", I. Course Notes. Accessed at http://www.yildiz.edu.tr/ okincay/d en.html, Date of Access: 10.02.2014

KINCAY, O (b)., (2008). "The LEED Certificate in Green Buildings", Course Notes. Accessed at www.yildiz.edu.tr/ okincay/dersnot u/Yesil_VBol_LEED.pdf, Date of Access: $12.1 \overline{2} .2013$

KINCAY, O (c)., (2008). "Sustainable Green Buildings", II. Course Notes. Accessed

at http://www.yildiz.edu.tr/ okincay/d en.html, Date of Access: 10.02.2014

RIES, R., BILEC, M. M., GOKHAN, N. M., NEEDY, K. L., (2006). "The Economic Benefits of Green Buildings: A Comprehensive Case Study", The Engineering Economist, 51: 259-295. Accessed at

http://www.tandfonline.com/doi/ab s/10.1080/00137910600865469\#pr eview, Date of Access: 12.02.2014

ALBASZADEH, S., ZAGREUS, L., LEHRER, D., HUIZENGA, C., (2006). "Occupant Satisfaction with Indoor Environmental Quality in Green Buildings", Proceedings of Healthy Buildings, 3, 365-370. Accessed at http://escholarship.org/uc/item/9rf7 p4bs Keywords: green buildings, Date of Access: 10.01.2014

ZAFAR, S., (2013). "Features of a Green Building", Accessed at G: Iyesil_binalar|Features of a Green Building EcoMENA.htm, Date of Access: 01.02.2014

ESIN, T., YÜKSEK, $\quad \dot{I} ., \quad$ (2009). "Environmentally Friendly Ecological Structures", The 5th International Advanced Technologies Symposium (IATS'09), Karabük, May 2009, Accessed at iats09.karabuk.edu.tr/press/bildiril er_pdf/IATS09_08-99_415.pdf, Date of Access: 18.02.2014 